FACTA UNIVERSITATIS

Series: Economics and Organization Vol. 16, N ${ }^{\mathrm{o}} 4,2019$, pp. $403-414$

https://doi.org/10.22190/FUEO1904403J

Original Scientific Paper

\title{
POVERTY AS A HETEROGENEITY FACTOR IN EU COUNTRIES
}

UDC 364.662(4-672EU)

\section{Vesna Janković-Milić, Vinko Lepojević, Jelena J. Stanković}

\author{
University of Niš, Faculty of Economics, Niš, Serbia
}

\begin{abstract}
Measuring poverty is of utmost importance for any economy in order to look at the extent and causes of the vulnerability of the population, but also to formulate social and economic policy measures and measure their effects. The multidimensionality of poverty makes it difficult to quantify and measure it. The subject of research is the components of the AROPE (At risk of poverty and social exclusion) indicator in the countries of the European Union (EU). Using the cluster analysis, the EU countries were grouped into homogeneous units, after which the significance of the difference in the average values of the analyzed indicators was tested. Based on the obtained results, the hypothesis of pronounced heterogeneity of EU countries from the aspect of poverty was confirmed.
\end{abstract}

Key words: European Union, poverty, material deprivation, heterogeneity, cluster analysis.

JEL Classification: I32, C38, C12

\section{INTRODUCTION}

Poverty is one of the critical problems in the modern world. Although the number of the poor has more than halved since 1990, the United Nations maintain that one fifth of people in developing countries remain poor. That is why, and the fact that poverty threatens achievement in all other areas, ending poverty is a primary goal of the entire agenda. The goals under this objective are to eradicate extreme poverty, reduce to less than half of any form of poverty defined according to national criteria, and strengthen social and financial support for the poor.

Received July 05, 2019 / Revised October 11, 2019 / Accepted October 14, 2019

Corresponding author: Vesna Janković-Milić

University of Niš, Faculty of Economics, Trg kralja Aleksandra Ujedinitelja 11, 18000 Niš, Serbia

E-mail: vesna.jankovic@eknfak.ni.ac.rs 
UN member states' development policies will be guided by the 2030 Sustainable Development Goals defined by the UN Development Agenda for 2030 in the coming period. Poverty reduction is highlighted as the first goal of sustainable development, which points to the great importance attached to this aspect of development.

\section{POVERTY IN EUROPEAN UNION}

The rise in the number of people in Europe at risk of poverty has initiated one of the major innovations introduced in Europe 2020, adopted in 2010, a new common goal in the fight against poverty and social exclusion. The goal includes reducing the number of people living below the national poverty line by $25 \%$ and save more than 20 million people out of poverty (https://ec.europa.eu/social). To achieve this, the Commission launched the European Platform against Poverty and Social Exclusion in 2010 and presented a list of key initiatives such as the evaluation of active inclusion strategies at national level and the White Paper on pensions (COM:2012:0055:FIN:EN:PDF).

Until 2010, the main focus in measuring poverty at EU level was on relative poverty. Comparing relative poverty rates between countries does not sufficiently take into account differences in living standards (Blanchet et al, 2019). In reality, it is more a measure of inequality. For example, a person who is relatively poor in a rich country usually suffers less material deprivation than a person living in a country where the general standard of living is low. In these countries, poverty may be more extreme, people are more likely to lack the necessary things to live, so survival is more difficult, but the relative poverty rate is lower because the overall standard of living is low, i.e. the difference between the 'poor' and everyone else standard of living is smaller. This can lead to misunderstanding of the extent of poverty and even underestimation of the severity of poverty that some social groups are facing, especially in the new EU Member States. The most difficult situation is in those EU countries where the general standard of living is low and at the same time a high relative poverty rate. In order to take into account the different economic situations of different Member States, the values of the at-risk-of-poverty line should always be considered in parallel with the indicators of at-risk-of-poverty (Boarinni et al, 2006). In the European Union, relative poverty is measured using the line of relative income poverty. This indicator involves calculating the average or median national income.

Typically, poverty lines range between $40 \%$ and $70 \%$ of household income (Milosavljević, 2008). This generates a general at-risk-of-poverty rate, and these values can be further broken down by age, gender, household type and employment status to further clarify which social groups are at highest risk. In this way it is possible to explore the individual situations of specific groups such as children, the elderly, or the unemployed. Persons below $60 \%$ of the median income in the EU are considered to be at risk of poverty (Blanchet et al, 2019).

One of the drawbacks of the relative income poverty line is that determining a tipping point is a fairly arbitrary process. It tells us about the proportion of people who are poor, but does not sufficiently take into account other factors that affect their life situations, such as information about how far below the line they are or the duration of their poverty. 
Measuring the at-risk-of-poverty gap can help determine the situation of people below the poverty line, or the extent of poverty. The poverty risk gap measures the distance between the median equivalent income of persons below the at-risk-of-poverty threshold and the value of the at-risk-of-poverty threshold in terms of purchasing power.

AROPE - At risk of poverty or social exclusion is an indicator that reflects the multidimensionality of poverty and exclusion within the enlarged EU (Martić, 2015). This indicator is defined as the proportion of the population in at least one of the following situations (European Comission):

- exposure to the risk of poverty (households whose incomes are below the poverty line, i.e. below $60 \%$ of the median average national income);

- severe material deprivation;

- in households with low work intensity.

The composite AROPE indicator only covers part of the picture and does not describe the complexity of poverty. It is important to look at its three components separately.

Severe material deprivation implies that a household cannot afford at least 4 of the following options (Eurostat, 2009):

- to bear the unexpected, sudden financial costs;

- one week of annual leave outside the place of residence;

- one meat meal (red / chicken or fish) or vegetarian equivalent every other day;

- adequate home heating;

- durable goods, such as washing machine, colour TV, telephone, car;

- rent, loan instalments, overhead, which cannot be paid.

Very low working-intensity households are characterized by households in which the working-age persons have worked less than $20 \%$ of their total potential over the previous 12 months. Household intensity is the ratio of the total number of months that all household members of working age spent working during the reference year and the total number of months that the same household members could theoretically spend in the same period. A working age person is a person between the ages of 18 and 59, with the exclusion of students in the age group between 18 and 24 years (Eurostat, 2009).

In addition to those listed, it is important to measure other elements that capture the multidimensional nature of poverty. They include elements such as levels of debt, the extent of ill-health or disadvantage, the number of people living in inappropriate housing or poor environments, and the extent of inability to access public services.

\section{DATASET AND METHODOLOGY}

The subject of analysis in this paper is components of AROPE indicator in EU countries and Serbia. The basis for the analysis is EUROSTAT data for 2018. A key hypothesis in the research is that EU countries are very heterogeneous in terms of poverty. In order to confirm this hypothesis, the EU Member States were firstly grouped into homogeneous groups by cluster analysis, and then the significance of the difference in the average values of the components of the AROPE indicators between the formed groups of countries was tested. In addition, for each of the components, the position of the Republic of Serbia in relation to the EU level was analysed.

The At-risk-of-poverty rate is the primary component of the umbrella AROPE indicator. It is expressed as a percentage of persons at risk of poverty in the total population and by 
appropriate categories of sex and age at risk of poverty. The emphasis is placed on the number of persons at risk of poverty after social transfers, wherein the threshold is $60 \%$ of the median.

In the EU member states, the At-risk-of-poverty rate would be significantly higher than it would be if there were no social transfers. In the most generous and efficient systems, the relative income poverty rate decreases by $50 \%$ (in Denmark, Ireland, Luxembourg, Austria, Finland and Sweden) or more, while in the least efficient it decreases by only $20 \%$ or less (in Bulgaria, Greece and Italy). Poverty risk exposure indicators for the EU and Serbia in 2018 are shown in the following table:

Table 1 At-risk-of-poverty rate in EU countries and Serbia

\begin{tabular}{|c|c|c|c|}
\hline Country & $\begin{array}{c}\text { At risk } \\
\text { of poverty rate }\end{array}$ & $\begin{array}{c}\text { Rank } \\
\text { within EU }\end{array}$ & $\begin{array}{c}\text { Deviation from } \\
\text { EU average }\end{array}$ \\
\hline European Union & 16.9 & - & - \\
\hline Belgium & 16.4 & 14.5 & -0.5 \\
\hline Bulgaria & 22.0 & 4.0 & 5.1 \\
\hline Czechia & 9.6 & 28.0 & -7.3 \\
\hline Denmark & 12.7 & 25.0 & -4.2 \\
\hline Germany & 16.1 & 16.0 & -0.8 \\
\hline Estonia & 21.9 & 5.0 & 5.0 \\
\hline Ireland & 15.6 & 18.0 & -1.3 \\
\hline Greece & 18.5 & 10.0 & 1.6 \\
\hline Spain & 21.5 & 6.0 & 4.6 \\
\hline France & 13.3 & 22.5 & -3.6 \\
\hline Croatia & 19.4 & 8.0 & 2.5 \\
\hline Italy & 20.3 & 7.0 & 3.4 \\
\hline Cyprus & 15.7 & 17.0 & -1.2 \\
\hline Latvia & 23.3 & 2.0 & 6.4 \\
\hline Lithuania & 22.9 & 3.0 & 6.0 \\
\hline Luxembourg & 18.7 & 9.0 & 1.8 \\
\hline Hungary & 12.8 & 24.0 & -4.1 \\
\hline Malta & 16.8 & 13.0 & -0.1 \\
\hline Netherlands & 13.4 & 21.0 & -3.5 \\
\hline Austria & 14.3 & 20.0 & -2.6 \\
\hline Poland & 14.8 & 19.0 & -2.1 \\
\hline Portugal & 17.3 & 11.0 & 0.4 \\
\hline Romania & 23.5 & 1.0 & 6.6 \\
\hline Slovenia & 13.3 & 22.5 & -3.6 \\
\hline Slovakia & 12.4 & 26.0 & -4.5 \\
\hline Finland & 12.0 & 27.0 & -4.9 \\
\hline Sweden & 16.4 & 14.5 & -0.5 \\
\hline United Kingdom & 17.0 & 12.0 & 0.1 \\
\hline Serbia & 25.7 & - & 8.8 \\
\hline
\end{tabular}

Source: http://ec.europa.eu/eurostat/data/database 
According to the values of the indicator At-risk-of-poverty rate, presented in the Table 1, Romania has the highest rate within the EU (23.3), while the lowest is in the Czech Republic (9.6). In Serbia, the At-risk-of-poverty rate amounts to 25.7, which is higher compared to all EU countries. At EU level, the At-risk-of-poverty rate amounts to 16.9. Compared to this value, 16 member states have a poverty risk rate below this value, while in the remaining 12 countries, the At-risk-of-poverty rate is higher. A graphical representation of deviations from the EU level is shown on the Figure 1.

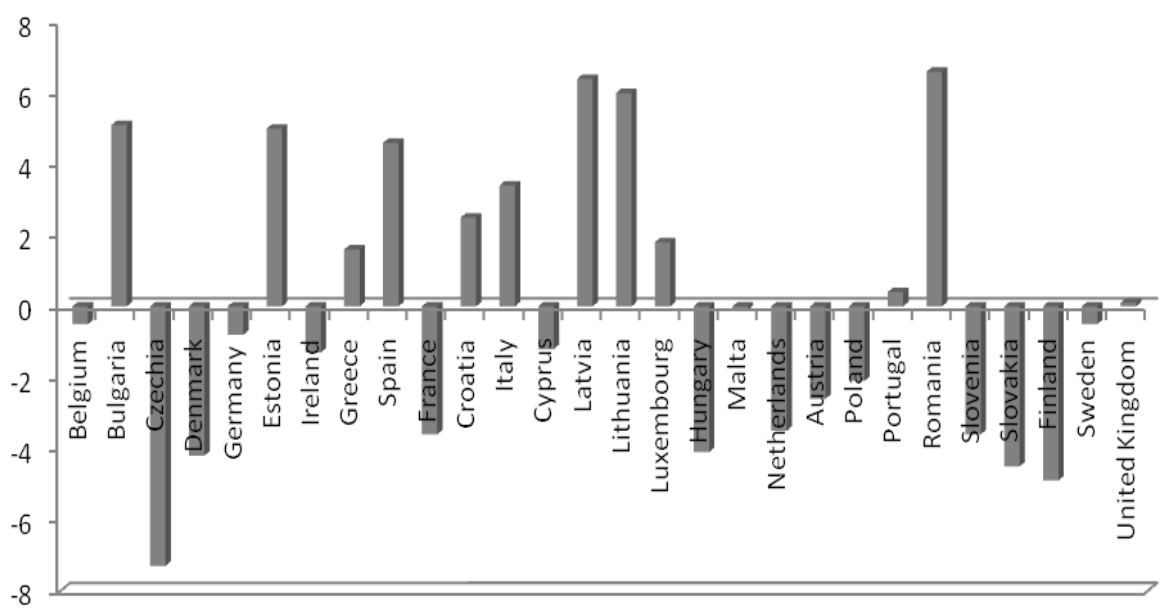

Fig. 1 At-risk-of-poverty rate - deviations from EU level Source: Forth column from Table 1

According to the Table 1, and Figure 1 also, countries with the At risk of poverty rate below the EU level are: Belgium, Czech Republic, Denmark, Germany, Ireland, France, Cyprus, Hungary, Malta, the Netherlands, Austria, Poland, Slovenia, Slovakia, Finland and Sweden. Other EU Member States, including: Bulgaria, Estonia, Greece, Spain, Croatia, Italy, Latvia, Lithuania, Luxembourg, Portugal, Romania and the UK, have Atrisk-of-poverty rate above EU level.

The use of deprivation indicators is another significant approach in measuring relative poverty. They are an attempt to move away from mere monetary, income indicators that take better account of a person's real standard of living. The approach involves identifying goods or activities that are considered essential needs in a particular country. In some countries, the measurement of poverty is based on the combination of the relative income line with indicators of deprivation. At EU level, extreme poverty is estimated using indicator Severe material deprivation. This indicator has limitations in terms of the small number of items it includes, as well as the lack of relevance of some of them, so its improvement is constantly being worked on. 
Table 2 Indicator Severe material deprivation in EU countries and Serbia

\begin{tabular}{|c|c|c|c|}
\hline Country & $\begin{array}{l}\text { Severe material deprivation (\% of } \\
\text { total population) }\end{array}$ & $\begin{array}{c}\text { Rank within } \\
\text { EU }\end{array}$ & $\begin{array}{c}\text { Deviation from } \\
\text { EU level }\end{array}$ \\
\hline European Union & 14.5 & - & - \\
\hline Belgium & 10.5 & 16.5 & -4.0 \\
\hline Bulgaria & 32.9 & 2.0 & 18.4 \\
\hline Czechia & 7.8 & 23.0 & -6.7 \\
\hline Denmark & 7.2 & 24.0 & -7.3 \\
\hline Germany & 9.1 & 20.0 & -5.4 \\
\hline Estonia & 9.9 & 19.0 & -4.6 \\
\hline Ireland & 14.8 & 12.0 & 0.3 \\
\hline Greece & 33.6 & 1.0 & 19.1 \\
\hline Spain & 13.9 & 13.0 & -0.6 \\
\hline France & 11.1 & 15.0 & -3.4 \\
\hline Croatia & 23.3 & 5.0 & 8.8 \\
\hline Italy & 16.8 & 9.0 & 2.3 \\
\hline Cyprus & 28.6 & 4.0 & 14.1 \\
\hline Latvia & 21.0 & 7.0 & 6.5 \\
\hline Lithuania & 23.1 & 6.0 & 8.6 \\
\hline Luxembourg & 4.4 & 28.0 & -10.1 \\
\hline Hungary & 19.6 & 8.0 & 5.1 \\
\hline Malta & 8.7 & 21.0 & -5.8 \\
\hline Netherlands & 6.5 & 25.0 & -8.0 \\
\hline Austria & 6.3 & 26.0 & -8.2 \\
\hline Poland & 10.5 & 16.5 & -4.0 \\
\hline Portugal & 16.6 & 10.0 & 2.1 \\
\hline Romania & 32.2 & 3.0 & 17.7 \\
\hline Slovenia & 10.4 & 18.0 & -4.1 \\
\hline Slovakia & 16.4 & 11.0 & 1.9 \\
\hline Finland & 8.0 & 22.0 & -6.5 \\
\hline Sweden & 4.5 & 27.0 & -10.0 \\
\hline United Kingdom & 12.3 & 14.0 & -2.2 \\
\hline Serbia & 30.7 & - & 16.2 \\
\hline
\end{tabular}

Source: http://ec.europa.eu/eurostat/data/database

According to the values of the indicators, severe material deprivation, within the EU, the most difficult situation is in Greece, where participation is $33.6 \%$, followed by Bulgaria (32.9\%), while the best situation is in Luxembourg (4.4\%). Analyzing the data for Serbia, it can be seen that the participation of the population in the state of severe material deprivation is lower than in Greece, Bulgaria and Romania, as it amounts to $30.7 \%$. Graphical representation of the EU countries rankings according to the indicator Severe material deprivation for one person is shown in Figure 2. 


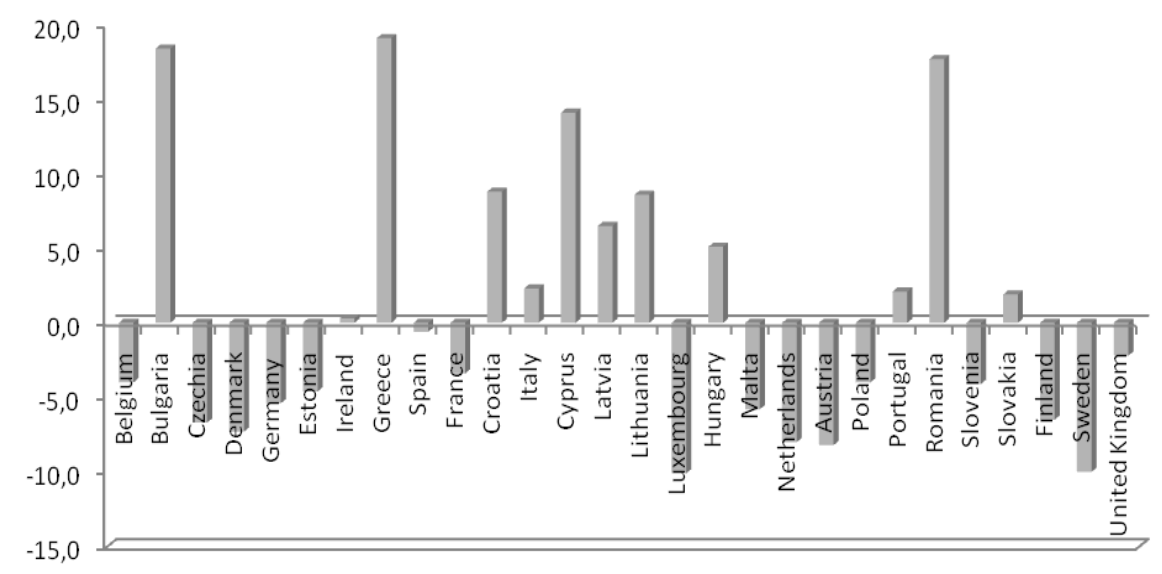

Fig. 2 Deviation from EU level according to indicator Severe material deprivation Source: The fourth column from the Table 2.

As with the At risk of poverty rate, 16 countries are below the EU level in terms of household participation in a severe material deprivation state, while 12 countries are above this level. It is necessary to emphasize that, although the number of countries is the same, their structure differs. Countries which have the higher values of this indicator, compared to the EU level, are: Bulgaria, Ireland, Greece, Croatia, Italy Cyprus, Latvia, Lithuania, Hungary, Poland, Romania and Slovakia.

According to the EU methodology, very low working-intensity households are households in which working age persons have worked less than $20 \%$ of their total potential over the previous 12 months. In the EUROSTAT database the values of this indicator are given for different categories of households (two-member, three-member, and four-member), as well as the total, i.e. average value by country. Further research will analyze in detail the average value by country.

As can be seen, the highest percentage of people living in very low working intensity households within EU countries is in Ireland (16.2) and Greece (14.6). The lowest percentage is characteristic of the Czech Republic, where it stands at 4.5, which is almost four times less than in Ireland. It can be concluded that this component of the AROPE indicator is characterized by a very large dispersion. According to this indicator, the Republic of Serbia is in a very unenviable position in relation to all EU countries, because the share of households with very low labour intensity is slightly above $20 \%(20.1 \%)$. 
Table 3 Percentage of the population living in very low working intensity households in EU countries and Serbia

\begin{tabular}{|c|c|c|c|}
\hline Country & $\begin{array}{l}\text { Very low working } \\
\text { intensity households }\end{array}$ & $\begin{array}{c}\text { Rank } \\
\text { within EU }\end{array}$ & $\begin{array}{c}\text { Deviation } \\
\text { from EU average }\end{array}$ \\
\hline European Union & 9.5 & - & - \\
\hline Belgium & 12.1 & 3.0 & 2.6 \\
\hline Bulgaria & 9 & 12.5 & -0.5 \\
\hline Czechia & 4.5 & 28.0 & -5 \\
\hline Denmark & 11.1 & 6.0 & 1.6 \\
\hline Germany & 8.7 & 14.5 & -0.8 \\
\hline Estonia & 5.2 & 27.0 & -4.3 \\
\hline Ireland & 16.2 & 1.0 & 6.7 \\
\hline Greece & 14.6 & 2.0 & 5.1 \\
\hline Spain & 10.7 & 8.0 & 1.2 \\
\hline France & 8.1 & 16.0 & -1.4 \\
\hline Croatia & 11.2 & 5.0 & 1.7 \\
\hline Italy & 11.3 & 4.0 & 1.8 \\
\hline Cyprus & 9.4 & 10.0 & -0.1 \\
\hline Latvia & 7.6 & 17.0 & -1.9 \\
\hline Lithuania & 9 & 12.5 & -0.5 \\
\hline Luxembourg & 6.9 & 21.0 & -2.6 \\
\hline Hungary & 5.7 & 22.0 & -3.8 \\
\hline Malta & 5.5 & 24.0 & -4 \\
\hline Netherlands & 8.7 & 14.5 & -0.8 \\
\hline Austria & 7.3 & 19.0 & -2.2 \\
\hline Poland & 5.6 & 23.0 & -3.9 \\
\hline Portugal & 7.2 & 20.0 & -2.3 \\
\hline Romania & 7.4 & 18.0 & -2.1 \\
\hline Slovenia & 5.4 & 25.5 & -4.1 \\
\hline Slovakia & 5.4 & 25.5 & -4.1 \\
\hline Finland & 10.8 & 7.0 & 1.3 \\
\hline Sweden & 9.1 & 11.0 & -0.4 \\
\hline United Kingdom & 10.1 & 9.0 & 0.6 \\
\hline Serbia & 20.1 & - & 10.6 \\
\hline
\end{tabular}

Source: http://ec.europa.eu/eurostat/data/database

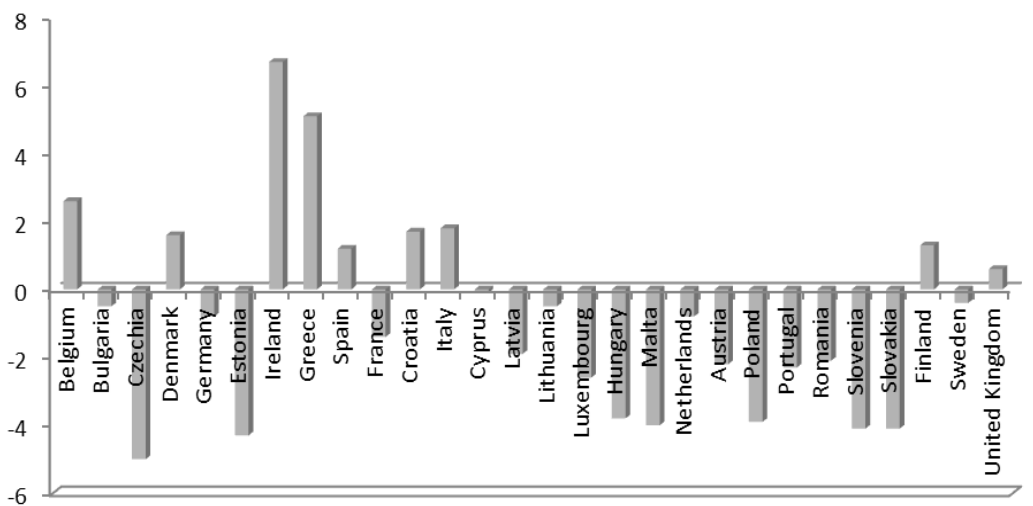

Fig. 3 People living in households with very low work intensity - deviation from EU level Source: The fourth column from the Table 3. 
Although this indicator is characterized by high dispersion, there is a small number of countries with share of households with very low working intensity higher than the EU level (9.5\%). More precisely, it is only 9 countries, which can be considered as one third of total membership: Belgium, Denmark, Ireland, Greece, Spain, Croatia, Italy, Finland and the United Kingdom.

By observing deviations from the EU level it can be seen that certain EU countries are in a very bad position. Namely, the values of all three components of the AROPE indicator in Greece, Croatia and Italy are above the EU level. The reasons for this position of these countries are numerous. The longstanding crisis and austerity measures in Greece have deepened poverty. Croatia is characterized by a large heterogeneous spatial distribution of poverty. In Italy, the population living in absolute poverty is constantly increasing.

\section{RESULTS AND DISCUSSION}

As part of the statistical analysis of the indicators presented, a correlation analysis was first performed, i.e. the correlation coefficients were calculated. With this measure, the direction and the degree of agreement of the indicators was assessed. As the assumptions for calculating the Pearson correlation coefficient are not fulfilled, the Spearman's rho correlation coefficient, as a non-parametric measurement of the interdependence between indicators, has been calculated. All components of the AROPE indicator are directly correlated. According to this coefficient, the highest interdependence exists between the components At-risk-of-poverty rate and Severe material deprivation $(\mathrm{r}=0.491, \mathrm{p}=0.008)$. Significantly lower and also insignificant correlation exists between Severe material deprivation and Low working intensity households $(\mathrm{r}=0.277, \mathrm{p}=0.153)$, as well as between At-risk-of-poverty rate and Low working intensity households $(\mathrm{r}=0.189, \mathrm{p}=0.336)$.

The analysis of the values of the components of the AROPE indicators indicates the great heterogeneity of EU countries. To group these into homogeneous entities, a hierarchical cluster analysis was applied (Everitt et al, 2011), with a predefined number of clusters (3). Ward's method was used as the clustering method and the Euclidean distance squared as a similarity measure. The number of countries in the clusters formed is different. There are 8 countries in the first cluster, 7 countries in the second cluster and 13 countries in the third cluster. The structure of the formed cluster is shown in the following table.

Table 4 Cluster membership

\begin{tabular}{lll}
\hline Cluster I & Cluster II & Cluster III \\
\hline Belgium & Bulgaria & Czechia \\
Ireland & Greece & Denmark \\
Spain & Croatia & Germany \\
Italy & Cyprus & Estonia \\
Hungary & Latvia & France \\
Portugal & Lithuania & Luxemburg \\
Slovakia & Romania & Malta \\
United Kingdom & & Netherlands \\
& & Austria \\
& & Poland \\
& & Slovenia \\
& & Finland \\
& & Sweden \\
\hline
\end{tabular}


Based on the values of the descriptive measures (Table 5), it can be concluded that in the second cluster, average rate of exposure to poverty risk is the highest (20.75), percentage of the population in severe material deprivation is the highest (27.81), while the average percentage of households with very low labour intensity is slightly below the highest average percentage (9.74), which otherwise binds to the first cluster (9.84). The least-poor countries, according to selected indicators, are countries belonging to the third cluster. Countries which are classified in the first cluster characterize the highest percentage of households with very low working intensity, a much lower At-risk-of-poverty rate (16.66) and the participation of the population in severe material deprivation (15.11) compared to the countries from the second cluster. As the values of the analyzed indicators in Serbia are higher than in the EU countries, it can be assumed that Serbia would belong to second cluster.

The highest dispersion, according to the indicators At-risk-of-poverty rate and the participation of very low work-intensity households, characterizes the countries belonging to the first cluster. Countries belonging to the second cluster, which can be characterized as the "poorest", although there are few, show the highest dispersion according to the value of indicator Severe material deprivation.

Table 5 Descriptive statistics

\begin{tabular}{|c|c|c|c|c|c|c|c|}
\hline \multirow[t]{2}{*}{ Indicator } & \multirow[t]{2}{*}{ Cluster } & \multirow[t]{2}{*}{ Mean } & \multirow{2}{*}{$\begin{array}{c}\text { Std. } \\
\text { Deviation }\end{array}$} & \multicolumn{2}{|c|}{$\begin{array}{l}95 \% \text { Confidence Interval } \\
\text { for Mean }\end{array}$} & \multirow[t]{2}{*}{ Min. } & \multirow[t]{2}{*}{ Max. } \\
\hline & & & & Lower Bound & Upper Bound & & \\
\hline \multirow{4}{*}{$\begin{array}{l}\text { At risk of } \\
\text { poverty rate }\end{array}$} & 1 & 16.66 & 3.19 & 13.99 & 19.33 & 12.4 & 21.5 \\
\hline & 2 & 20.75 & 2.96 & 18.02 & 23.50 & 15.7 & 23.5 \\
\hline & 3 & 14.87 & 3.16 & 12.96 & 16.78 & 9.6 & 21.9 \\
\hline & Total & 16.85 & 3.86 & 15.36 & 18.35 & 9.6 & 23.5 \\
\hline \multirow{4}{*}{$\begin{array}{l}\text { Severe } \\
\text { material } \\
\text { deprivation }\end{array}$} & 1 & 15.11 & 2.87 & 12.71 & 17.51 & 10.5 & 19.6 \\
\hline & 2 & 27.81 & 5.30 & 22.92 & 32.71 & 21.0 & 33.6 \\
\hline & 3 & 8.03 & 2.20 & 6.70 & 9.36 & 4.4 & 11.1 \\
\hline & Total & 15.00 & 8.74 & 11.61 & 18.39 & 4.4 & 33.6 \\
\hline \multirow{4}{*}{$\begin{array}{l}\text { Low working } \\
\text { intensity } \\
\text { households }\end{array}$} & 1 & 9.84 & 3.63 & 6.80 & 12.87 & 5.4 & 16.2 \\
\hline & 2 & 9.74 & 2.48 & 7.45 & 12.04 & 7.4 & 14.6 \\
\hline & 3 & 7.45 & 2.17 & 6.14 & 8.76 & 4.5 & 11.1 \\
\hline & Total & 8.71 & 2.88 & 7.59 & 9.82 & 4.5 & 16.2 \\
\hline
\end{tabular}

In order to determine the significance of the difference in the average values of the selected indicators, Kruskal-Wallis test has been applied. The Kruskal-Wallis test (also called the "one-way ANOVA on ranks") is a rank-based nonparametric test. It is considered the nonparametric alternative to the one-way ANOVA, and an extension of the MannWhitney $\mathrm{U}$ test to allow the comparison of more than two independent groups.

The characteristics of the clusters formed can also be observed based on the average rank values (Table 6). The lowest average rank values for all indicators refer to the third cluster, followed by the first and finally the second cluster. Since the testing was conducted at 0.05 significance level, the test results proved a statistically significant difference between the clusters according to the indicators At-risk-of-poverty rate ( $\mathrm{p}=$ $0.007)$ and Severe material deprivation ( $\mathrm{p}<0.0001$ ), while in the case of low work intensity this difference was not confirmed. 
Table 6 Results of Kruskal-Wallis test

\begin{tabular}{|c|c|c|c|c|c|}
\hline Indicator & Cluster & Mean Rank & Chi-Square & df & Sig. \\
\hline \multirow{3}{*}{ At risk of poverty rate } & 1 & 14.19 & \multirow{3}{*}{10.071} & \multirow{3}{*}{2} & \multirow{3}{*}{0.007} \\
\hline & 2 & 22.57 & & & \\
\hline & 3 & 10.35 & & & \\
\hline \multirow{3}{*}{$\begin{array}{l}\text { Severe material } \\
\text { deprivation }\end{array}$} & 1 & 17.31 & \multirow{3}{*}{22.823} & \multirow{3}{*}{2} & \multirow{3}{*}{0.0001} \\
\hline & 2 & 25.00 & & & \\
\hline & 3 & 7.12 & & & \\
\hline \multirow{3}{*}{$\begin{array}{l}\text { Low working intensity } \\
\text { households }\end{array}$} & 1 & 17.44 & \multirow{3}{*}{4.911} & \multirow{3}{*}{2} & \multirow{3}{*}{0.086} \\
\hline & 2 & 18.00 & & & \\
\hline & 3 & 10.81 & & & \\
\hline
\end{tabular}

\section{CONCLUSION}

Poverty is nowadays most commonly seen as a multidimensional concept, which is also reflected in the overarching official definitions adopted by the European Union and the United Nations. It is a problem faced by a large number of countries, regardless of their level of economic development. It can also be stated that poverty is a multidimensional phenomenon which, in addition to insufficient income to meet basic living needs, also includes aspects related to human rights, such as: inability to find employment, inadequate housing, inadequate access to social protection, health and utilities, etc. For the purpose of combating poverty and inequality in the EU, the aforementioned Europe 2020 Strategy has been defined, but numerous pilot projects and programs, various treaties and other acts have been adopted, the Directives adopted (Racial Equality 2000/43 / EC, Employment 2000/78 / EC, Equal Treatment of Women and Men 2006/54 / EC) and various incentive measures presented.

Adequate measuring is a very important factor in the process of combating poverty. For this purpose, the complex AROPE indicator, whose components are analyzed in this paper, has been created. But, this indicator covers only part of the picture and does not describe the complexity of poverty. A statistically significant difference in the average values of the selected indicators is in favour of confirming the key hypothesis in the survey, that is, EU Member States are very heterogeneous in terms of poverty. The observed and statistically confirmed differences in the poverty rate of the EU Member States suggest that it is very important to regulate this issue at the national, regional and local levels with policies, strategies and other guidelines.

Acknowledgement: The authors are grateful to the Ministry of Education, Science and Technological Development of the Republic of Serbia for the funds and support that made this research possible.

\section{REFERENCES}

Blanchet, T., Chancel L. \& Gethin A. (2019). How Unequal Is Europe? Evidence from Distributional National Accounts, 1980-2017. Retrieved from: https://wid.world/document/bcg2019-full-paper/ Accessed on: 19 May 2019.

Boarini, R. \& Mira d'Ercole, M. (2006). Measures of Material Deprivation in OECD Countries. In: OECD social, employment and migration working papers. 
Brewer, M. \& O’Dea, C. (2012). Measuring Living Standards with Income and Consumption: Evidence from the UK. Institute for Social \& Economic Research Working Paper Series (2012-05).

Calve, T.J., Benson, P.G. \& Sincich, T. (2002). Statistics for business and economics. New Jersey.

Đorđević V., Lepojević V. \& Janković-Milić V. (2011). Primena statističkih metoda u istraživanju tržišta [Application of statistical methods in market research]. Niš: Ekonomski fakultet.

European Commission. (2009). Portfolio of indicators for the monitoring of the European Strategy for Social Protection and Social Inclusion - 2009 update. Retrieved from: http://ec.europa.eu/KE-06-14-163-ENN\%20(5).pdf Accessed on: 29 September 2018.

Eurostat, European social statistics pocketbook - All social statistics on the EU in one publication 112/2013. Retrieved from: http://ec.europa.eu/eurostat/documents/ 3930297/5968986/KS-FP-13-001-EN.PDF/ Accessed on: 29 September 2018.

Eurostat, People at risk of poverty or social exclusion by age group. Retrieved from: http://epp.eurostat.ec. europa.eu/statistics_explained/index.php?title=File:People_at_risk_of_poverty_or_social_exclusion_by_age_group ,2012.png\&filetimestamp=20131203134426. Accessed on: 29 September 2018.

Eurostat. (2013). Statistical matching of EU-SILC and the Household Budget Survey to compare poverty estimates using income, expenditures and material deprivation. Eurostat Methodologies and Working papers. Retrieved from: https://ec.europa.eu/eurostat/documents/3888793/5857145/KS-RA-13-007-EN.PDF/37d4ffcc-e9fc-42bc8d4f-fc89c65ff6b1 Accessed on: 14 April 2019.

Eurostat. (2013). The measurement of poverty and social inclusion in the EU: achievements and further improvements. The way forward in poverty measurement. Geneva: United Nations Economic Commission For Europe.

Everitt, B., Landau, S., Leese, M. \& Stahl D. (2011). Cluster Analysis. John Wiley \& Sons, USA

Fisher, G.M. (1992). The Development and History of the Poverty Thresholds. Social Security Bulletin, 55 (4), 3-14.

Fusco, A., Guio, A.C. \& Marlier, E. (2010). Characterising the Income Poor and the Materially Deprived in European Countries. In B. A. Atkinson, \& E. Marlier, Income and Living Conditions in Europe (pp. 133-155). Luxembourg: Publications Office of the European Union.

Gordon, D. (2006). The Concept and Measurement of Poverty. In: C.G. Pantazis, Poverty and Social Exclusion in Britain (pp. 29-69). Bristol: The Policy Press.

Hair, J.F., Black, W.C., Babin, B.J. \& Anderson, R.E. (2010). Multivariate Data Analysis-A Global Perspective, Upper Saddle River NJ, Pearson Education

Kraatz, S. (2016). Borba protiv siromaštva, socijalne isključenosti i diskriminacije [Combating poverty, social exclusion and discrimination]. Retrieved from: http://www.europarl.europa.eu/atyourservice/hr/displayFtu. html?ftuId=FTU_5.10.9.html. Accessed on: 04 May 2019.

Martić, M. (2015). Dimenzije $i$ pokazatelji socijalne marginalizacije sa posebnim osvrtom na Bosnu $i$ Hercegovinu [Dimensions and indicators of social marginalization with special reference to Bosnia and Herzegovina]. GEA - Centar za istraživanja i studije.

Milosavljević, M. (2008). Siromaštvo u svetu i u Srbiji [Poverty in the world and in Serbia], Socijalna misao. 4, Beograd.

Rencher, A. (2002). Methods of Multivariate Analysis, John Wiley \& Sons, USA.

World Bank (WB), Working for a World Free of Poverty, Retrieved from: http://iresearch.worldbank.org/ PovcalNet/index.htm?1 Accessed on: 04 May 2019.

World Hunger Notes, (2013) World Hunger and Poverty Facts and Statistics. Retrieved from: http://www.worldhunger. org/articles/Learn/world\%20hunger\%20facts\%202002.htm Accessed on: 19 May 2019.

\section{SIROMAŠTVO KAO FAKTOR HETEROGENOSTI ZEMALJA EVROPSKE UNIJE}

Merenje siromaštva je od izuzetnog značaja za bilo koju ekonomiju radi sagledavanja razmera i uzroka ugroženosti stanovništva, ali i radi formulisanja mera socijalne i ekonomske politike $i$ merenja njihovih efekata. Multidimenzionalnost siromaštva u velikoj meri otežava njegovu kvantifikaciju i merenje. Predment istraživanja u ovom radu su komponente AROPE (At risk of poverty and social exclusion) indikatora u zemljama Evropske Unije (EU). Primenom klaster analize zemlje Evropske Unije svrstane su u homogene celine, a nakon toga ispitana je značajnost razlike u prosečnim vrednostima analiziranih pokazatelja. Na osnovu dobijenih rezultata potvrđena je hipoteza o izraženoj heterogenosti zemalja EU sa aspekta siromaštva.

Ključne reči: Evropska unija, siromaštvo, materijalna deprivacija, heterogenost, klaster analiza. 